\title{
NF1 Gene Mutation
}

National Cancer Institute

\section{Source}

National Cancer Institute. NF1 Gene Mutation. NCI Thesaurus. Code C118388.

A change in the nucleotide sequence of the NF1 gene. 